\title{
Knowledge Sharing in Strategic Alliance Relationships: An Empirical Research on Hotels in Turkey
}

\author{
Nilüfer Vatansever Toylan ${ }^{1 *}$, Fatih Semerciöz ${ }^{2}$ and Masood-Ul-Hassan ${ }^{3}$
}

\author{
${ }^{1}$ Department of Tourism Management, Kırklareli University, Turkey, E-mail: nilufer.vatansever@klu.edu.tr \\ 2 Department of Business Management and Organization, Istanbul University, Turkey, E-mail: \\ fsemerci@istanbul.edu.tr \\ 3 Department of Commerce, Bahauddin Zakariya University Multan, Pakistan, E-mail: masood@bzu.edu.pk \\ ${ }^{*}$ Corresponding author
}

\begin{abstract}
The study aims to investigate the influence of inter-organizational knowledge sharing enablers-communication, trust, shared vision, commitment, learning intent, and absorptive capacity directly and indirectly through interorganizational knowledge sharing process on behavioural innovation outcome in strategic alliances of 4- \& 5-stars hotels of world heritage cities of Istanbul and Antalya. For data collection, the quota sampling method is applied to select the 250 senior hotel executives engaged in collaborative strategic hospitality alliances. Besides, to test the hypotheses, descriptive, correlation as well as regression analyses are performed through the SPSS. The current study finds that the six facets of relational and social capital inter-organizational knowledge sharing enablers offered and examined have significant impacts, directly and indirectly through inter-organizational knowledge sharing process on the innovative behavioural outcome of hospitality alliance firms. The results imply that the hospitality industry in its policy agenda should recognize that relational and social capital-based knowledge sharing strategic alliances can be a vital source of collaborative innovation. Finally, the current research also provides the empirical recognition of historic cities of Turkey as cultural destinations, so emphasizing the appropriateness of world heritage cities to investigate inter-firm relationships across hospitality alliance firms.
\end{abstract}

Keywords: Inter-Organizational Knowledge Sharing, Alliances, Hospitality, Innovativeness

Citation: Toylan, N.V., Semerciöz, F, \& Hassan, M.U. (2020). Knowledge Sharing in Strategic Alliance Relationships: An Empirical Research on Hotels in Turkey. European Journal of Tourism Research 24, 2403

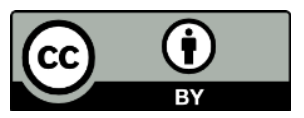




\section{Introduction}

The ability to create and diffuse knowledge both at intra and inter-firm level is becoming growingly more vital in a contemporary knowledge-based economy. Empirical studies over the past three decades show that an organization may significantly increase its knowledge and innovative abilities by capitalizing the capabilities of others through the sharing of knowledge both within and across firms (Dyer and Singh, 1998; Easterby-Smith, Lyles, \& Tsang, 2008; Chen, Lin, \& Yen, 2018). The underlying assumption for the existence of such "organizations of organizations" (Provan, 1983) is that as opposed to the unity of command based hierarchical forms, knowledge-creating resources command more value to produce more innovation in alliance firms including traveling and tourism (Zach and Hill, 2017).

Specifically, in hospitality functioning, since, knowledge is concerned to a firm's offerings, customers, competitors, operational methods, and job associates (Yang and Wan, 2004), therefore, sharing knowledge between firms carries more complication because of the complex nature of the cultures, processes, and boundaries involved. It is, thus, an attracting area for further theoretical investigation in strategic alliances (Easterby-Smith et al., 2008). Therefore, Kim, Lee, Paek, and Lee (2013) asserted that to effectively execute knowledge management, a comprehensive understanding of the interrelationship among its variables-knowledge sharing enablers, its processes, and outcomes-is essential in hospitality organizations.

Although Knowledge management has become apparent over the past 20 years as one of the most discussed management perspectives, however, in the tourism sector, it has not attained the same amount of empirical research and applications as in other domains (Kim and Shim, 2017). Nevertheless, after an epochal work in the field (Hall, 1999 in terms of issue of partnership in tourism from a public policy perspective; Jamal and Getz, 1995 in terms of multi-stakeholder processes for destination management and planning) within the standpoint of destinations as 'networks', tourism researchers started to analyze inter-firm knowledge sharing vis-à-vis cluster theory, social capital, cooperation, community tourism, and strategic management (Kim and Shim, 2017). However, still as compared to other fields, in hospitality industry, academicians and policymakers have not tried to incorporate holistically relational and social capital factors such as trust, commitment, learning intent, shared vision, absorptive capacity and communication (Hamel, 1991; Inkpen and Crossan, 1995; Lane and Lubatkin, 1998; Grant and Baden-Fuller, 2004; Inkpen and Tsang, 2005; Merlo, Bell, Mengüç, \& Whitwell, 2006; Nahapiet and Ghoshal 1998; Yli-Renko, Autio, \& Sapienza, 2001; Molina-Morales and Martínez-Fernández, 2010) as inter-organizational knowledge sharing enablers in to an integrative model that explores its relationship with inter-organizational knowledge sharing processes (Kale, Singh, \& Perlmutter, 200o; Kogut \& Zander, 1992), and firm innovation behaviour (Hurt, Katherine, \& Chester, 1977; Maggioni, Marcoz, \& Mauri, 2014).

Keeping in view these backgrounds, the aim of current study is to propose an integrative model that investigates the impact of inter-organizational knowledge sharing (KS) enablers-trust, commitment, learning intent, shared vision, absorptive capacity and communication-on process-interorganizational knowledge sharing behaviour-as a means to behavioural innovation outcome in strategic alliances of 4- \& 5-stars hotels of world heritage cities of Istanbul and Antalya. In other words, the present study target to examine the mediation role of inter-organizational knowledge sharing process in the relationship of inter-organizational knowledge sharing enablers and outcome. To this end, the current study hypothesizes a KS enablers-process-outcome model (Figure 1) to assume that based on inter-organizational relational factors, alliance actors share their work-related experience, expertise, know-how, and contextual information (Liu, 2018) to produce both intra and 
inter alliance-based behavioural innovativeness outcome-willingness of the firm to get newness from partners (Hurt et al., 1977; Maggioni et al., 2014).

The current study contributes to the existing literature. Firstly, the current research shows how interorganizational knowledge sharing behaves as an intermediary variable between inter-organizational relational and social capital factors, and innovative behaviour. Secondly, the present study provides theoretical enlightenments and empirical confirmation in support of innovation as a combination of intra and inter alliance-based innovation, and inter-organizational knowledge sharing as a relational capital to transfer know-how and learning across the alliance partners in tourism destinations. Thirdly, the current study underpins association between the relational view of inter-organizational competitive advantage (Dyer \& Singh, 1998), social capital perspective (Nahapiet and Ghoshal 1998), knowledge-based view (Nonaka, 1994) and Schumpeterian view of innovations (Schumpeter, 1934) in terms of creation of new knowledge from the assimilation of external knowledge with existing one as a key to generate innovation (Elche, Martínez-Pérez, \& García-Villaverde, 2017). Fourthly and finally, the current work underscores the originality of a context of research, the cultural tourism destinations of the World Heritage Cities-Istanbul and Antalya-of Turkey.

The remainder of this paper discusses the research context, literature review and hypotheses development, research methodology, research findings, discussion and conclusion, followed by theoretical and practical implications. Finally, the paper presents the study limitations and future directions.

\section{Research Context}

Following the security incidents and failed coup in the year 2016, Turkey has been ranked among the top 10 countries regarding international tourist arrivals-39,478,ooo-however, in terms of receipts$\$ 26,616$.o million-moved down five points to 17 th position. Moreover, having a world ranking of 44 th out of 133 in terms of Traveling and Tourism (T\&T), Turkey T\&T industry contributed 5\% and 2.3\% to GDP and employment respectively (World Economic Forum, Travel \& Tourism Competitiveness Report, 2017; United Nations World Tourism Organization, Tourism Highlights, 2017). However, out of total foreign visitors, $50 \%$ of foreign visitors preferred to visit destinations of Istanbul (36\%) and Antalya respectively. Moreover, in terms of a tourism operation, licensed rooms by the city in Turkey, Antalya was the leader with 193.506 rooms, followed by Istanbul with 51.483 .

Besides, international hotel groups with different brands - Accor, Best Western, Carlson Rezidor, Hilton, Hyatt, InterContinental, Marriott, and Wyndham have recognized the long-term potential of Turkey, and have remained committed to putting considerable investments in the country (Ernst Young, Tourism Industry Oversea, 2017).

Therefore, to ensure the Traveling and Tourism (T\&T) sustained growth in an uncertain security environment while protecting the local and natural environment on which it so enormously relies, the Ministry of Culture and Tourism of Turkey envisioned to transform Turkey within 5 top world brands in tourism destinations in terms of highest number of tourist and revenues by the end of 2023 (Ministry of Culture and Tourism, 2007). However, in comparison to this vision, in Global Competitiveness Index 2016-2017 report, overall, Turkey drops four places to 55th and in innovation ranked as 71 out of 136 world economies. Thus, a sound innovation tourism service ecosystem (Barile, Ciasullo, \& Triosi, 2017), where individuals or firms across the service ecosystem collaborate on innovation is needed to increase the Turkish T\&T industry's competitiveness (WEF, Global 
Competitiveness Index, 2016-2017) by the adoption of new or improved market offerings, processes, managerial techniques and market search (OECD-Eurostat, 2005).

\section{Literature Review}

This section after characterizing the current global hotel market dynamics within the context of value co-creation, presents the details about the nature of knowledge sharing hospitality alliances followed by its knowledge-based view.

As one of the fastest growing industries globally, tourism is regarded as a dynamic subscriber to wealth and job creation, cultural preservation, poverty alleviation, and environmental protection. Therefore, more than any other business sector, the current global hotel market is characterized by consolidations, take-overs, and strategic alliances. The harnessing of hospitality's positive contribution to sustainable development calls for substantial strategic equity and non-equity-based partnerships by all tourism stakeholders to foster innovation in line with the 2030 agenda for sustainable development (Chathoth \& Olsen, 2003; UNWTO, 2018).

Therefore, as firms in hospitality sector co-creating the image and meaning of the destinations (Saraniemim \& Kylanen, 2011), constant innovative behaviour is vital during competing with other organizations in the same destination as well as during cooperating to contest with other destinations for well dynamic visitors (Hjalager, 2010b). Thus, value is co-created by all players participated throughout the practice of the experience, as soon as knowledge is shared (Prahalad \& Ramaswamy, 2004) through the inherent structure of the industry. Hence, service viewpoint can increase such knowledge sharing by persons or organizations as a system of service exchange-application of resources i.e., knowledge and skills for the benefit of another. Thus, the relational nature of service exchange enables knowledge sharing that stimulates innovation (Greer, Lusch, \& Vargo, 2016). Due to these features, along with the globalization of the tourism sector, the hotel industry especially is forced to offer an immediate and successful customer experience that is valuable to consumers from diverse cultures. Therefore, to gain a competitive edge, tourism sectors are bound to formulate and execute novel strategies to appeal to customers by offering experiences that have not previously been made available (Gomezelj, 2016).

However, behind the innovative activity in destinations, knowledge is a critical factor, whether external or internal (Camisón, Boronat-Navarro, \& Forés, 2018), incorporated or tacit (localized), incorporated (Hjalager, 2010a), analytical, synthetic or symbolic (Asheim, Boschma, \& Cooke, 2011). Notably, in the emerging knowledge-based society, the capacity to share knowledge beyond tourism organizations has been shown to impart to their innovative behaviour (Zach \& Hill, 2017) in terms of improvement in tourism including products, services, and experiences (Hjalager, 2010a), and developments in creating client relationship (Ottenbacher \& Gnoth, 2005). Therefore, it is crucial to understand likelihood for rival tourism organizations with the complementary or similar market offerings. For the stated reason, these should work together via strategic alliances and provide channel to outside knowledge bases, as an important input, to the innovative practices of tourism organizations. Consequently, this helps in bring additional tourists to a destination for the shared advantage of all key players (von Friedrichs Grängsjö and Gummesson, 2006).

\section{Knowledge Sharing Hospitality Alliances}

Nevertheless, comprehending knowledge denotes recognition for the complexities of accessing, sharing, and assimilating knowledge in a learning climate, where firms cannot develop knowledge until and unless individual knowledge is shared with other persons and teams (Inkpen,1998, p.69- 71) 
to create new services in hotel industry (Tang, Wang \& Tang, 2015). Therefore, in the hospitality sector, team members are ever more sharing their knowledge and experience to supply innovative offerings (Hu, Horng, \& Sun, 2009). Hotel managers wishing to increase service capacity must assimilate extensively disintegrated knowledge into innovative offerings (Nicolau \& Santa-Maria 2013). However, the possible part of alliances in empowering destinations and organizations to approach useful outside sources of knowledge is a necessary prerequisite for improving their competitive edge (Van Niekerk, De Martino, \& Scott, 2017, p.5). Therefore, collaborative alliances have been demonstrated to facilitate organizational and destinations innovation, respectively (Denicolai, Cioccarelli, \& Zucchella, 2010). Simply put, in hospitality destinations, alliances and innovation are instantly interweaved and much valuable (Zach \& Hill, 2017).

Within the context of knowledge sharing in tourism alliances, Jetter and Chen (2012, p. 132) defined both 1) collaboration as "a process in which two or more individuals possessing complementary skills and attributes interact to create a shared meaning or understanding that could not have been created without the other individual", and 2) strategic alliances as "purposive, inter-organizational relationships, in which the organizations share similar goals, strive for mutual benefits, and have an understanding of a high level of mutual dependence". Therefore, in tourist destinations, to boost competencies, market offerings as well as competitive position globally, alliances between (a) buyerssellers; (b) suppliers-distributors; (c) multiple suppliers, and (d) training \& research centers in the value chain often requires allied firms to share knowledge so as to establish a shared knowledge base which assists as a 'platform' whereupon they can better simply create innovative knowledge-based resources (Grant and Baden-Fuller, 2000; Okumus, Altinay, \& Chathoth, 2010; Koo, Ricci, Cobanoglu, \& Okumus, 2017).

Therefore, in destination literature, alliances and collaborations in terms of interdependence, complementary skills, shared meaning (goals) and mutual benefits incline to focus on three dominant theoretical paradigms: transactions cost (Williamson, 1975), resource dependency (Pfeffer and Salancik, 1978), and social exchange theory (Dwyer, Schurr, \& Oh, 1987). However, no individual theoretical approach is presently able to describe the complicated nature of destination collaboration (Wang and Xiang, 2007). Besides, innovating denotes employing knowledge to develop a new understanding (Drucker, 1993), and social relationships contribute a vital part in this activity (Nonaka \& Takeuchi, 1995; Nonaka, 1994; Kogut \& Zander 1992). Therefore, the current research is grounded on the context of hospitality strategic alliances that provides an exciting and rich contextual base to study the inter-organizational knowledge sharing enablers-process-outcome phenomenon. The study incorporated the relational, social capital, and knowledge-based theoretical lenses (Dyer \& Singh, 1998; Inkpen \& Tsang, 2005; Grant \& Baden Fuller, 2004; Nahapiet \& Ghoshal, 1998) with innovative behaviour in the cultural tourism destinations (Hjalager, 201ob; Van Niekerk et al., 2017; Zach \& Hill, 2017; Liu, 2018).

\section{Knowledge-based View of Knowledge Sharing Hospitality Alliances}

The knowledge-based view (KBV) of the alliances brings a new point of view to inter-firm collaboration by acquiring and assimilating knowledge to produce innovative offerings (Capaldo, 2014). The knowledge-based theory provides that the primary aim of alliances is to increase the productivity of every ally's knowledge usage via integration of knowledge (Grant \& Baden-Fuller, 200o). This collaborative innovation in alliance firms is the result of the convergence process of tacit (personal, trying to communicate) with explicit (codified, transmittable) knowledge in four different ways (Okumus, 2013): 
$\checkmark$ Tacit-to-tacit-socialization-sharing experiences to create shared mental models-In hotel a worker can acquire new knowledge from his/her superior or coworker listening and observing by how clients' grievances are handled.

$\checkmark$ Tacit-to-explicit-externalization-expressing and articulating knowledge using analogiesEmployees of a section in a hotel can discuss routine client grievances and together create specific strategies and directions describing how to answer to clients' grievances.

$\checkmark$ Explicit to tacit-internalization-learning by doing- A hotel worker can undertake a nonidentical perspective and may notice that this innovative way functions. In this case, this worker has tacit knowledge.

$\checkmark$ Explicit to explicit-combination-systemize concepts into a knowledge system- A hotel undertaking may opt their standard hotel opening manual to create a manual for resort openings.

Thus, the knowledge creation process is represented as a helix, working at the individual, group, firm, and inter-firm levels, in which socialized knowledge is externalized, systemized via combination, and later internalized, in virtue of creating a new and improved round of developing socialized knowledge, and so forth (Nonaka \& Takeuchi, 1995).

\section{Hypotheses Development}

\section{Effects of Inter-Organizational Knowledge Sharing Process upon Innovative Behaviour}

While, technologies likely to build on trajectories, however, innovative offerings incline to demand a creative mix of new knowledge. Besides, to serve the market as a leader with innovative offerings often requires the capability to recognize, approach, and assimilate rapidly beyond the kinds of knowledge needed for a creative product class. Therefore, the current study proposes that since tourism (hotels) alliances can exploit specialized expertise across multiple products, thus, are better to both internal administrations within the tourism organization and tourism market contracts. Besides, the current study further argues that alliance partners in the hotel industry as the most important source of new ideas and information through knowledge sharing practices can allow the sharing, creation, or recombination of knowledge that results in the innovative behavioural outcome (Grant \& BadenFuller, 200o). These are structured inter-organizational methods that are intentionally planned to enable knowledge sharing between networked firms (Dyer \& Singh, 1998, p. 665).

In other words, it means that innovation is created through retrieving, harnessing, and assimilating flows of knowledge beyond the organizational boundaries (Chesbrough, 2017, p. 35) including tourism where businesses operate through networks of relationships in geographical proximity (Von Friedrichs Grängsjö \& Gummesson, 2006). This collaborative innovation depends on purposively managed inter-organizational knowledge sharing by using (non) idiosyncratic mechanisms to motivate and guide knowledge sharing (Chesbrough \& Bogers, 2014). Thus, within the hotel industry, the broadest value proposition is that knowledge sharing could generate firm innovation (e.g. development of new marketing offerings, growth of firm performance outside a mere internal vision that targets to combine their competitiveness over other hotels to include an external view where relational capabilities play a vital part in exchange of knowledge for joint learning and innovation (Rodríguez-Díaz \& Espino-Rodríguez, 2006). Thus, keeping in view the above, the current study hypothesizes:

Hypothesis 1: Inter-organizational Knowledge sharing process has a positive association with innovative behavioural outcome of firms in hospitality alliance. 


\section{Relational E Social Capital as Innovative Knowledge Sharing Enablers}

While, alliances involve co-development, exchange, and sharing of resources, however, our interest is alliances in which partners gain access to the skills and knowledge of their partners (Inkpen,1998, p 70; Gulati \& Gargiulo, 1999, p. 1440) to generate innovations (Capaldo, 2014). However, acquiring of knowledge has been known as a direct benefit of relational or social capital (Nahapiet \& Ghoshal, 1998). The current study, therefore, seeks to understand how knowledge is shared within hospitality alliances and how relational and social capital affects the knowledge shared to generate innovation.

In this regard, as an addition of the resource-based perspective, the relational view proposes that competitive edge obtains not merely from organizational resources, but also hard-to-copy skills rooted in alliance relationships (Dyer \& Singh, 1998). Thus, by developing knowledge-sharing practices, relation-specific resources, and successful relational governance systems into alliances, organizations can capitalize their relational assets for knowledge exploration and exploitation (Yli-Renko et al., 2001). Notably, the more alliance firm absorptive capacity to identify and integrate innovative knowledge from their alliance companion is the more possibility to create innovative relational rents by knowledge sharing (Dyer \& Singh, 1998). Whereas, the essential idea of the social capital view is that alliances through the constructs of relational, structural, and cognitive constructs of their social capital-trust, strong ties, and shared vision-offer accession to invaluable resources including knowledge acquiring, combination, and transfer to create value (Nahapiet \& Ghoshal, 1998; Nieves \& Osorio, 2013). Therefore, the current study suggests the following constructs of relational \& social capital as innovative knowledge sharing enablers:

$\checkmark$ Communication: Strong ties in alliances mirrors the proximity of relationship between allies and enhances with the frequency of closeness and communication (Hansen, 1999). It is therefore presumed that quality communication in terms of strong ties within alliances will result in more efficient and to the point multifaceted knowledge sharing outcomes than weak ties (Reagans \& McEvily, 2003). Therefore, tourism firms' collaboration with multiple partners to share knowledge to develop innovations further mainly depends on open, frequent, timely, accurate, and relevant quality communication (Beritelli, 2011). Thus, effective interorganizational communication facilitates tourism firms to let other partners share knowledge on innovation development dynamically (Zach, 2016).

$\checkmark$ Trust: Rivals hotels with identical market offerings and the target segments have prospered in utilizing social capital to inculcate trust in one another. The belief of trust has motivated them to undertake diverse marketing approaches. Thus, the prevalence of relational trust between firms in business contexts enables the sharing of opportunity exploration and exploitation, besides of organizational and technical knowledge, in manners that assist to a win-win situation in hospitality alliances (von Friedrichs Grängsjö \& Gummesson, 2006). Thus, inter-organizational trust is a particularly significant factor in participant-governed destination alliances and is the core of business relationships and raises the intention of knowledge acquisition and sharing beyond firms' boundaries (Beaumont \& Dredge, 2010).

$\checkmark$ Shared Vision: As partners of alliance firms share values and collective vision, they will get nearer and more eagerly to interact and share job-related knowledge as time fallows, and more probably to increase the accumulated existing skills and knowledge (Li and Chang, 2016). Sharing same vision and goals during work allow workers to develop into peers, shared out innovative problem-solving routines, boost the pace of knowledge sharing and improve individual's capacities (Carmeli, Gelbard, \& Reiter-Palmon, 2013). Thus, sharing knowledge encompasses a plethora of data and is particularly vital in a hospitality destination alliance as knowledge sharing warrants assurance to shared vision (Shaw \& Williams, 2009). 
$\checkmark \quad$ Learning Intent: Alliance partners' knowledge sharing cannot guarantee innovations unless the embedded firms assume that firm learning is depended upon accession to innovative knowledge and the abilities for utilizing and creating on such knowledge (Inkpen, 1998, p. 69). Thus, in knowledge-based alliances, learning effectiveness is primordial (Serrat, 2017). Therefore, the hospitality organizations should always modify their learning capacity to develop social capital quickly, that can facilitate the productive knowledge sharing of attained prospects and in enhancing overall productivity. However, such learning ability to gather social capital to further lead adequate knowledge sharing to generate innovation in the cultural and creative firms of hospitality sector originates from their higher level of learning intention (Liu, 2018) or tendency to consider collaboration as a learning opportunity (Hamel, 1991) that impacts the alliance firm's decision to originate learning and generate new knowledge (Inkpen, 2000).

$\checkmark$ Commitment: Much knowledge is nuanced, subtle, and difficult to verify, thus, partners do not fully consider impersonal sources (Granovetter, 2005), and, therefore, sharing, exchange, or co-inventing in alliances follow continuous commitment between the partners (Gulati \& Gargiulo, 1999, p. 1440) that can provide basis of relational social norms to develop productive long-term relations (Gundlach, Achrol, \& Mentzer, 1995). Partner commitment is the disposition of the partners regarding allocating necessary resources towards the alliance and forfeiting short-term profits against long-term gains of the alliance (Gundlach et al., 1995). Moreover, trust-commitment theory (Morgan \& Hunt, 1994) underlines the significance of collaboration across alliances to compete successfully within swift dynamic competing environments. Relational trust and commitment are two primary constructs that motivate firms to counter opportunistic behaviours and thus, protect long-term relational rents (Chen, Lin, \& Yen, 2014).

$\checkmark$ Absorptive Capacity: Without partners' absorptive capacity 'to recognize the value of new knowledge and assimilate the knowledge for commercial purposes' (Inkpen, 1998, p. 75), organizations cannot deploy outside knowledge to earn their competitive edge (Tzokas, Kim, Akbar, \& Al-Dajani, 2015). Therefore, absorptive capacity facilities organizations to rapidly realize and assimilate outside knowledge and to dynamically shift that know-how into leading offerings (Peltokorpi, 2017). Thus, the transition of knowledge sharing into better firm performance can only materialize if there was a positive absorption capacity for innovative thoughts (Levitt \& March, 1988). Notably, in the hospitality and tourism sector, absorptive capacity allows organizations to identify the worth of external knowledge profitably to generate innovation (Pace, 2016).

Thus, relational and social capital through its dimensions facilitates the generation of innovative knowledge. Therefore, especially, in hospitality sector, recent research on knowledge sharing through relational or social capital has started to acknowledge the central part of the different constructs of relational and social capital to generate innovation (Martínez-Pérez, García-Villaverde, \& Elche, 2016; Tang, 2016; García-Villaverde, Elche, Martínez-Pérez, \& Ruiz-Hortega, 2017; Zach \& Hill, 2017; Liu, 2018; Idrees, Vasconcelos, \& Ellis, 2018; Camisón et al.,2018). Therefore, by following the seminal studies (Inkpen \& Tsang, 2005; Dyer \& Singh, 1998; Nahapiet \& Ghoshal, 1998; Kogut \& Zander, 1992), the current study proposes that in hospitality industry, the degree to which partners utilize their alliances to gain and exploit knowledge is governed by relational and social capital based interorganizational knowledge sharing enablers such as communication, trust, and shared vision (Merlo, Bell, Mengüç, \& Whitwell, 2006; Nahapiet \& Ghoshal 1998: Yli-renko et al., 2001; Molina-Morales \& Martínez-Fernández, 2010) as well as learning intent (Hamel, 1991), absorptive capacity (Levitt \& 
March, 1988), and commitment (Gundlach et al.,1995). So, keeping in view the above discussion, the current study further hypothesizes:

Hypothesis 2a-2f: Inter-organizational knowledge sharing enablers-(a) communication, (b) trust, (c) shared the vision, (d) commitment, (e) learning intent, and (f) absorptive capacity each has a positive association with inter-organizational knowledge sharing process.

Hypothesis 3a-3f: Inter-organizational knowledge sharing process mediates the relationship between Inter-organizational Knowledge sharing enablers-(a) communication, (b) trust, (c) shared the vision, (d) commitment, (e) learning intent, and (f) absorptive capacity each respectively and innovative behavioural outcome of firms in hospitality alliance.

Hypothesis 4a-4f: Inter-organizational knowledge sharing enablers-(a) communication, (b) trust, (c) shared the vision, (d) commitment, (e) learning intent, and (f) absorptive capacity each has a positive association with innovative behavioural outcome of firms in hospitality alliance.

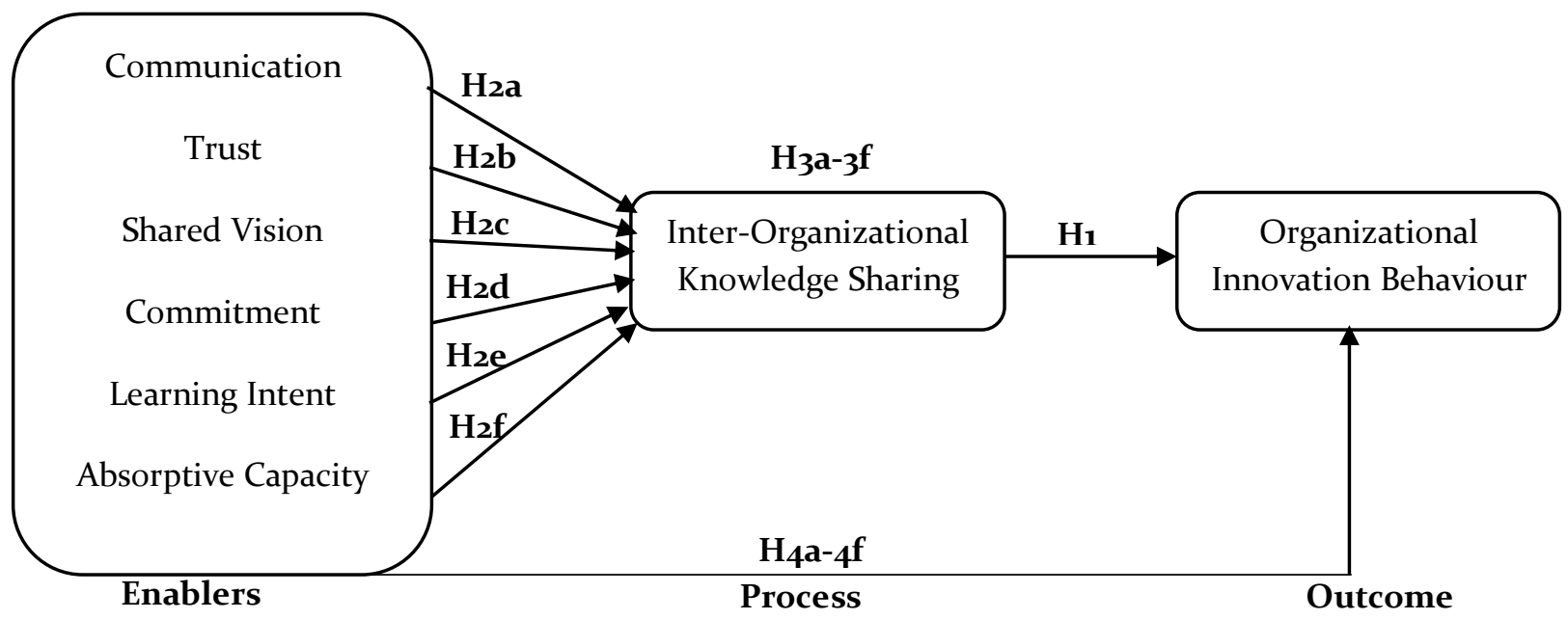

Figure 1. Research Model

\section{Methodology}

Data Collection and Sampling

The research hypotheses developed in the preceding part were tested by utilizing survey data gathered from the senior executives (i.e., presidents, CEOs, vice-presidents, directors, or general managers) engaged in collaborative strategic alliances of Antalya and Istanbul based national and international 4 and 5-star certified Turkish hotels by Ministry of Culture and Tourism. The reason to choose the provinces of Istanbul and Antalya is that being one of the oldest cultures of Turkey; they are at the top world cultural heritage cities-cum-tourist hotspots in the list of the global sea-sand-sun tourism destinations. Moreover, as per 2017 tourism figures, Forbes Travel has placed Istanbul as $6^{\text {th }}$ out of $10^{\text {th }}$ as world's top most-visited cities. On the other hand, Antalya is the most preferred city in Turkey based on the number of incoming foreign visitors. Therefore, more than half of the national and international branded hotels (e.g., Hilton, Dedeman, Rixos, and Sheraton, etc.) in the country are massed in these two provinces (Investment Support and Promotion Agency of Turkey, 2018; Ernst Young, Tourism Industry Oversea, 2017). Moreover, a phenomenon of strategic alliance formation mostly practiced in large-scale organizations (Norman, 2004), and congruency with respect to organizational structure and size exists between 4 and 5 -star hotels, therefore, for data collection, list 
and contact information of 4 and 5 stars certified hotels located in Istanbul and Antalya was obtained from the Turkish Ministry of Culture and Tourism. Specifically, Antalya and Istanbul have over 500 and 200 4\&5-star hotels, respectively (Investment Support and Promotion Agency of Turkey, 2018; Ernst Young, Tourism Industry Oversea, 2017). Therefore, more than seven hundred 4 and 5-star national and international hotels created the population of the current study. However, to save time and to minimize cost, a non-probabilistic version of stratified sampling and survey methodology, the quota sampling method was applied (Acharya, Prakash, Saxena, \& Nigam, 2013) to select the percentage-statistical sample of individuals from within a statistical population of seven hundred $4 \& 5$ star certified hotels of Antalya and Istanbul. As a result, with, 95\% confidence, 5 percent-plus/minusprecision, 50 percent proportion of the population which has the attribute in question, and $\mathrm{Z}$ values of 1.96, the current study achieved a sample size of 248 (Cochran, 1963). Thus, 300 survey questionnaires were distributed. Out of them, a total of 250 were collected. However, out of these 250 collected questionnaires, after deducting 20 odd filled ones, the remaining 230 were processed for final analysis.

\section{Survey Instrument}

The measurement scale of the constructs used in the current study were adapted from valid, reliable, and well-established scales (see Table1). Furthermore, to motivate the sample executives of $4 \& 5$ hotels to complete the survey, the cover letter was initially provided in the instrument. Besides, to create the shared meaning among the sample respondents, the definition of the strategic alliance was also offered in the instrument. Moreover, as a Likert-type instrument presumes that the strength of experience is linear, i.e., on a continuum from strongly agree to strongly disagree (Likert, 1932), therefore, the respondents were advised to rate the statements included in sections 2, 3, and 4 by using 5-point scale (5-definitely agree, 4-agree, 3-neither agree nor disagree, 2-disagree, 1-strongly disagree). However, the first section of the questionnaire included the statements concerning existence, duration, type, and sector of a strategic alliance relationship as well as ownership type of hotel, extranet to share information and data, service development unit, and several stars, rooms, and employees.

Besides, the second section within the context of strategic alliances included the 27 statements related to inter-organizational knowledge sharing enablers-(a) communication, (b) trust, (c) shared vision, (d) commitment, (e) learning, and (f) absorptive capacity adapted from previous research (see Table 1). Besides, with 11 statements adapted from previous research (see Table1), the third section of the survey instrument was targeted to measure to inter-organizational knowledge sharing behaviours (process) of the hotels within the strategic alliance formation. Moreover, in the fourth section with 8 statements targeted to measure the innovativeness outcome possessed by the hotels, also adapted from the previous research (see Table 1).

Table 1. Constructs and Scale References

\begin{tabular}{ll}
\hline Construct (scales) & References \\
\hline Trust & Li (2005); Norman (2004); Mohr and Speakman (1994); Inkpen (1992) \\
Learning Intent & Norman (2004); Inkpen (1992) \\
Communication & Cheng et al. (2008); Mohr and Speakman (1994) \\
Absorptive Capacity & Malhotra et al. (2005) \\
Shared vision & Li and Lin (2006) \\
Commitment & Li and Lin (2006) \\
Interorganizational & Kale (2000); Kogut and Zander (1992); Simonin (1999); Lee (2001); Chen \\
$\quad$ knowledge sharing & (2004) \\
Innovativeness & Hurley and Hult (1998); Calantone et al. (2002); Maggioni et al. (2014) \\
\hline
\end{tabular}


Finally, by following the existing research, the back-translation strategy was utilized (Brislin, 1980; cited in Hassan \& Ayub, 2019). Therefore, initially, the survey statements were produced in English and were then translated into Turkish. Subsequently, the research statements were converted back into English to avoid the difference of the sense generated by language translation (Köseoglu, Yazici, \& Okumus, 2017).

\section{Validity and Reliability of Instruments}

To shape the latent formation of the measurement model (Brown, 2006), the 44-item measurement instrument comprising 27-item-inter-organizational knowledge sharing enablers, 11item-interorganizational knowledge sharing process, and 8-item-innovativeness outcome each was submitted to principal component factor analysis (PCA) under varimax rotation through SPSS. The aim was to provide validity for constructs used in the analysis by reducing the larger set of 44-statements into a smaller set of inter-organizational knowledge sharing enablers, inter-organizational knowledge sharing process, and innovativeness outcome (Hair, Black, Babin, Anderson, \& Tatham, 1998). As a result of the factor analysis (see Table 2), out of twenty-seven, 24 statements with factor loadings of more than 0.50 value as well as with Kaiser-Meyer-Olkin (KMO) measure of sample adequacy (Williams, Onsman, \& Brown, 2010) value of 0.890, loaded into six factors of the inter-organizational knowledge sharing enablers-(a) communication, (b) trust, (c) shared vision, (d) commitment, (e) learning, and (f) absorptive capacity. Moreover, together, these six inter-organizational knowledge sharing enablers (factors) explained 70.565 percent of the total variance explained. Besides, the reliabilities for these inter-organizational knowledge sharing facilitators in terms of Cronbach's alpha values were between 0.65 and o.88, which were considered acceptable (Gliem \& Gliem, 2003).

Similarly, the results of the factor analysis of 11 statement-inter-organizational knowledge sharing process (see Table 2) with factor loadings of more than 0.50 value as well as with Kaiser-Meyer-Olkin (KMO) measure of sample adequacy value of 0.920 , loaded into one factor explained 59.04\% of the total variance explained. Besides, the reliability of inter-organizational knowledge sharing process in terms of Cronbach's alpha value calculated as 0.927 , which was considered as excellent (Gliem \& Gliem, 2003). However, the results of the factor analysis of 8-statement-innovativeness outcome (see Table 2) with factor loadings of majority of the items exceeding over 0.50 value as well as with KaiserMeyer-Olkin (KMO) measure of sample adequacy value of 0.812 , loaded into two factors jointly explained 63.948 percent of the total variance explained. Besides, the reliability of these two factors of hotels innovativeness in terms of Cronbach's alpha values ranges from 0.736 to 0.835 , which were considered acceptable (Gliem \& Gliem, 2003). However, for final analysis, these two factors of innovativeness outcomes were merged into single factor.

Table 2. Validity and Reliability Analysis

\begin{tabular}{lcccc}
\hline Constructs and items & Mean & SD & $\begin{array}{c}\text { Indicator } \\
\text { Loadings }\end{array}$ & $\begin{array}{l}\text { Cronbach's } \\
\text { Alpha }\end{array}$ \\
\hline $\begin{array}{l}\text { Absorptive Capacity } \\
\begin{array}{l}\text { Our Alliance partner enables us to develop } \\
\quad \text { products/services for end customers. }\end{array}\end{array}$ & 4.18 & 0.834 & 0.748 & $\mathbf{0 . 8 8 4}$ \\
$\begin{array}{l}\text { Our alliance partner enables us to find better ways to } \\
\quad \text { market the products/services. }\end{array}$ & 4.15 & 0.865 & 0.732 \\
$\begin{array}{l}\text { Our alliance partners allow us to better understand } \\
\quad \text { the competencies of our competitors. }\end{array}$ & 4.05 & 0.965 & 0.724 \\
$\begin{array}{l}\text { Our alliance partner enables us to develop the } \\
\text { strategies needed to compete in the market }\end{array}$ & 4.18 & 0.834 & 0.723 & \\
\hline
\end{tabular}


Our alliance partner enables us to understand the needs of our customers better.

Our alliance partner helps us better understand the market segments we serve.
4.22
0.771
0.723
4.11 $\quad 0.859 \quad 0.690$

$4.46 \quad 0.638 \quad 0.790$

$\begin{array}{lll}4.36 & 0.763 & 0.765\end{array}$

$\begin{array}{lll}4.29 & 0.738 & 0.745\end{array}$

$\begin{array}{lll}4.36 & 0.678 \quad 0.725\end{array}$

$4.39 \quad 0.657 \quad 0.723$

$\begin{array}{lll}4.14 & 0.869 & 0.579\end{array}$

\section{Trust}

Our alliance partner respect the confidentiality of the information they receive from us.

Our alliance partner has been open and honest in dealing with us.

We trust that our alliance partner's decisions will be beneficial to the alliance.

There is a high level of trust in the working relationship with our alliance partner.

We can rely on our partner to abide by the alliance agreement.

We trust that our partner's decisions will be beneficial to our hotel.

\section{Mutual Commitment}

Our alliance partners abide by agreements very well.

We have invested a lot of effort in our relationship with alliance partners.

We and our alliance partners always try to keep each other's promises.

$\begin{array}{llll}\text { Our alliance partners have made sacrifices for us in } & 3.63 & 1.143 & 0.529\end{array}$ the past.

\section{Learning Intent}

As a result of this alliance, we have improved existing technical skills

As a result of this alliance, we have developed new management skills.

As a result of this alliance, we have developed new technical skills.

\section{Shared vision}

We and our alliance partners have a similar understanding about the aims and objectives of the collaboration.

We and our alliance partners have a similar understanding about the importance of collaboration.

We and our alliance partners have a similar understanding about the importance of

\subsection{0}

$\begin{array}{lll}4.18 & 0.735 & 0.758 \\ 4.13 & 0.850 & 0.736 \\ 4.34 & 0.686 & 0.706 \\ 3.63 & 1.143 & 0.529\end{array}$

$3.04 \quad 1.277 \quad 0.882$

0.854

$\begin{array}{lll}3.28 & 1.281 & 0.861 \\ 3.21 & 1.253 & 0.812\end{array}$

$4.14 \quad 0.811 \quad 0.758$

0.823 improvements that benefit the collaboration.

\section{Communication}

Our hotel and alliance partner frequently exchange each other's opinions

Our alliance partner frequently keeps us informed of new developments

$\begin{array}{lll}4.16 & 0.782 & 0.669\end{array}$

$\begin{array}{lll}4.10 & 0.766 & 0.575\end{array}$

0.828 


\section{Knowledge Sharing}

In order to develop competitive products or services, our hotel creates and shares knowledge with strategic alliance partners.

Our hotel regularly conducts meetings with strategic alliance partners for the purpose of communication and knowledge developing and sharing.

Our hotel and strategic alliance partners create a "community" that allows strategic alliance members to share and create knowledge.

You and your partner share know-how from work experience with each other

Our hotel and alliance partner learn from each other sufficiently about business activities (distribution, sales-marketing, service production, $R$ \& D, etc.)

Our hotel and alliance partner share knowledge obtained from newspapers, magazines, journals, television and other sources

Our hotel and alliance partner work together to create new skills and knowledge.

Our hotel uses all its resources (financial, technical, physical, administrative, people, etc.) to support the sharing of knowledge.

Our hotel and alliance partner share significant proportion of knowledge with each other.

Our hotel and alliance partner share each other's know-where and know-whom

Our hotel and alliance partner share a lot of information about how to improve each other's capacities.

\section{Alliance based innovation}

We routinely gather information about prospective partners from various forums (e.g., trade shows,

4.05

0.882

0.846

3.96

0.984

0.811

$3 \cdot 93$

0.936

0.811

4.03

$0.95^{2}$

0.811

$\begin{array}{lll}3.87 & 1.014 & 0.802\end{array}$

$\begin{array}{lll}3.96 & 0.956 & 0.794\end{array}$

$\begin{array}{lll}3.98 & 0.943 & 0.775\end{array}$

$\begin{array}{lll}3.66 & 1.104 & 0.775\end{array}$

$\begin{array}{lll}4.02 & 0.900 & 0.745\end{array}$

$\begin{array}{lll}3.70 & 1.095 & 0.667\end{array}$

$\begin{array}{lll}4.02 & 0.898 & 0.572\end{array}$ industry conventions, databases, publication, internet, etc.)

We actively monitor our environment to identify partnering opportunities

We are alert to market developments that create potential alliance opportunities

Our new products/services introduction has increased after the collaboration 


\section{Internal Innovation}

Our hotel frequently tries out new ideas products and services

Innovation in our hotel is perceived as too risky and is resisted (reverse)
4.08

0.890

0.675

4.10

0.870

0.583

3.45

0.995

0.424

\subsection{6}

$\begin{array}{lll}3.51 & 0.881 & 0.417\end{array}$

\section{Results}

Table 3 reveals the sample's profile.

Table 3. Sample Profiles of Hotels and Alliance Relations

\begin{tabular}{lll}
\hline Characteristics & Frequency & Percentage \\
\hline Number of stars & & \\
4-star hotels & 95 & 41.3 \\
5-star hotels & 135 & 58.7 \\
Total & 230 & 100 \\
\hline Position of ownership & & \\
Private/Independent & 128 & 55.7 \\
National chain & 50 & 21.7 \\
International chain & 18 & 7.8 \\
Partnership & 27 & 11.7 \\
Group company & 7 & 3.0 \\
Total & 230 & 100 \\
\hline Hospitality Alliance types & & \\
Marketing alliance & 130 & 56.5 \\
Technology based alliance & 26 & 11.3 \\
Management contract & 24 & 10.4 \\
Franchise & 18 & 7.8 \\
Alliance with competitors & 7 & 3.0 \\
Alliance with suppliers & 12 & 5.2 \\
Joint venture & 12 & 5.2 \\
Other & 1 & 0.4 \\
Total & 230 & 100 \\
\hline Industry of alliance partner & & \\
Travel & 74 & 32.2 \\
Food and beverage (e.g. restaurants) & 6 & 2.6 \\
Transportation & 3 & 1.3 \\
Accommodation & 125 & 54.3 \\
Entertainment & 1 & 0.4 \\
Organization & 4 & 1.7 \\
Rent a car & 2 & 0.9 \\
Spa wellness- Health & 2 & 0.9 \\
Logistic & 1 & 0.4 \\
Architecture & 4 & 1.7 \\
Information and Communication & 3 & 1.3 \\
Textile & 2 & 0.9 \\
Food (FMCG) & 3.3 \\
\hline
\end{tabular}




\begin{tabular}{lll}
\hline $\begin{array}{l}\text { Duration of contract with alliance partner } \\
\text { Less than 1 year }\end{array}$ & 33 & 14.3 \\
1-5 years & 127 & 55.2 \\
6-10 years & 36 & 15.7 \\
More than 10 years & 34 & 14.8 \\
\hline Alliance with other companies & \\
Yes & 222 & 96.5 \\
No & 7 & 3 \\
Unanswered & 1 & 0.5 \\
\hline Extranet to share information and data & & \\
Yes & 160 & 69.4 \\
No & 70 & 30.6 \\
\hline Whether hotels have a service development unit & & \\
Yes & 176 & 76.5 \\
No & 54 & 23.5 \\
Total & 230 & 100 \\
\hline
\end{tabular}

Descriptive and Correlation Analysis

The means, standard deviations and bivariate Pearson correlations between the variables have been found through the SPSS-Version 20 software (see Table 4). The respondents rated the trust variable highest (mean=4.353), followed by communication (mean=4.233), absorptive capacity $(\operatorname{mean}=4.161)$, shared vision (mean=4.146), commitment (mean=4.076), knowledge sharing (mean=3.977), innovativeness (mean=3.895), and learning intent (mean=3.227). Moreover, the value of the standard deviation of the majority of the constructs is less than 1.

Table 4. Means, standard deviations and cross-correlations

\begin{tabular}{lllllllllll}
\hline Variables & Mean & SD & 1 & 2 & 3 & 4 & 5 & 6 & 7 & 8 \\
\hline 1. AC & 4.161 & 0.68 & 1 & & & & & & & \\
2. Trust & 4.353 & 0.56 & $0.499^{* *}$ & 1 & & & & & & \\
3. CMT & 4.076 & 0.72 & $0.612^{* *}$ & $0.55^{* *}$ & 1 & & & & \\
4. LI & 3.227 & 1.14 & $0.273^{* *}$ & 0.089 & $0.204^{* *}$ & 1 & & & \\
5. SV & 4.146 & 0.68 & $0.580^{* *}$ & $0.549^{* *}$ & $0.602^{* *}$ & $0.213^{* *}$ & 1 & & & \\
6. COM & 4.233 & 0.71 & $0.527^{* *}$ & $0.426^{* *}$ & $0.445^{* *}$ & $0.328^{* *}$ & $0.428^{* *}$ & 1 & & \\
7. KS & 3.977 & 0.74 & $0.622^{* *}$ & $0.473^{* *}$ & $0.565^{* *}$ & $0.333^{* *}$ & $0.544^{* *}$ & $0.543^{* *}$ & 1 & \\
8. INN & 3.895 & 0.59 & $0.320^{* *}$ & $0.219^{* *}$ & $0.235^{* *}$ & $0.323^{* *}$ & $0.240^{* *}$ & $0.240^{* *}$ & $0.348^{* *}$ & 1 \\
\hline
\end{tabular}

Note: $\mathrm{AC}=$ Absorptive Capacity; $\mathrm{CMT}=$ Commitment; $\mathrm{LI}=$ Learning Intent; $\mathrm{SV}=$ Shared Vision; COM= Communication; KS= Knowledge Sharing; INN= Innovativeness; ** Correlation is significant at the o.o1 level (2tailed); Based on $\mathrm{n}=230$

Besides, the bivariate Pearson Correlation with the help of correlation coefficient $(r)$ demonstrates the robustness of linear association and its plus (minus) sign shows the direction of relationship. The results revealed that inter-organizational knowledge sharing process has positive and significant relationship with inter-organizational knowledge sharing enablers: absorptive capacity $(r=0.622$, $\mathrm{p}=0.01)$ followed by commitment $(r=0.565, \mathrm{p}=0.01)$, shared vision $(r=0.544, \mathrm{p}=0.01)$, communication $(r=0.543, \mathrm{p}=0.01)$, trust $(r=0.473, \mathrm{p}=0.01)$, and learning intent $(r=0.333, \mathrm{p}=0.01)$. In addition, the results revealed that hotels alliances innovativeness has positive and significant relationship with interorganizational knowledge sharing process $(r=0.348, \mathrm{p}=0.01)$ followed by inter-organizational knowledge sharing enablers: learning intent $(r=0.323, \mathrm{p}=0.01)$, absorptive capacity $(r=0.320, \mathrm{p}=0.01)$, 
shared vision $(r=0.240, \mathrm{p}=0.01)$, communication $(r=0.240, \mathrm{p}=0.01)$, commitment $(r=0.235, \mathrm{p}=0.01)$, and trust $(r=0.219, \mathrm{p}=0.01)$.

\section{Hypotheses Testing}

To prove mediation, Baron and Kenny (1986) provided that three preconditions must be applied: Firstly, the independent variable-inter-organizational knowledge sharing enablers: (a) communication, (b) trust, (c) shared vision, (d) commitment, (e) learning, and (f) absorptive capacity each should impact the mediator-inter-organizational knowledge sharing process-in the first regression equation. Secondly, the independent variable-inter-organizational knowledge sharing enablers: (a) communication, (b) trust, (c) shared vision, (d) commitment, (e) learning, and (f) absorptive capacity each should be revealed to impact the dependent variable-innovative behavioural outcome-in the second regression equation. Thirdly, the mediator inter-organizational knowledge sharing process must influence the dependent variable-innovative behavioural outcome-in the third regression equation. Baron and Kenny (1986) further provided that if these preconditions all hold on to the predetermined path, then the influence of the independent variable on the dependent variable should be lower in the third regression equation than in the second. Besides, perfect mediation applies if the independent variable has no influence when the mediator is controlled.

Therefore, in the current study, by following the Baron and Kenny (1986), a four-step method in which various regression analyses were performed and the significance of the beta coefficients was studied at each stage. The basic aim of steps 1-3 was to ensure that without controlling or holding constant any factor, whether zero-order significant correlation exists among study variables. As shown in table 5 , in step-1, the results of regressions from 3 a to $3^{f}$ showed that significant and positive relationship exist between inter-organizational knowledge sharing enablers and innovative behavioural outcome (IBO): trust and IBO $\left(\beta=0.357, p<0.001, R^{2}=10.6 \%\right)$, followed by absorptive capacity and IBO $\left(\beta=0.339, p<0.001, R^{2}=11.5 \%\right)$, communication and IBO $\left(\beta=0.273, p<0.001, R^{2}=7.4 \%\right)$, shared vision and IBO $\left(\beta=0.357, p<0.262, R^{2}=8.5 \%\right)$, commitment and IBO $(\beta=0.242, p<0.001$, $\left.\mathrm{R}^{2}=8.3 \%\right)$, and learning intent and IBO $\left(\beta=0.160, \mathrm{p}<0.001, \mathrm{R}^{2}=9.4 \%\right)$.

Besides, as shown in Table 5, in step 2, the results of regressions analyses from 2 a to 2 f showed that significant and positive relationship exist between inter-organizational knowledge sharing enablers and inter-organizational knowledge sharing process (IKSP): absorptive capacity and IKSP $(\beta=0.628$, $\left.\mathrm{p}<0.001, \mathrm{R}^{2}=39.2 \%\right)$, followed by shared vision and IKSP $\left(\beta=0.622, \mathrm{p}<0.262, \mathrm{R}^{2}=38.5 \%\right)$, commitment and IKSP $\left(\beta=0.585, p<0.001, R^{2}=34 \%\right)$, communication and IKSP $\left(\beta=0.557, p<0.001, R^{2}=30.7 \%\right)$, trust and IKSP $\left(\beta=0.511, p<0.001, R^{2}=34 \%\right)$, and learning intent and IKSP $\left(\beta=0.373, p<0.001, R^{2}=13.5 \%\right)$. Moreover, as shown in Table 5, in step-3, the result of regression-1 showed that significant and positive relationship exists between inter-organizational knowledge sharing the process and innovative behavioural outcome $\left(\beta=0.459, \mathrm{p}<0.001, \mathrm{R}^{2}=\mathbf{2 0 . 7} \%\right)$. Besides, $\mathrm{R}$-square values vary maximally to $11.5 \%, 39.2 \%$, and $20.7 \%$ in step 1,2 , and 3 respectively. Keeping in view these significant relationships from steps 1 through 3 , hypotheses $\mathrm{H}_{1}, \mathrm{H} 2 \mathrm{a}-\mathrm{f}$, and $\mathrm{H}_{3} \mathrm{a}-\mathrm{f}$ all were accepted, hence mediation was considered possible, and, therefore, the current study further proceeded to step 4 .

Besides, as shown in Table 5 , in $4^{\text {th }}$ step of multiple regression model, when regressed on the dependent variable-innovative behavioural outcome-, the independent variable-inter-organizational knowledge sharing enablers (except learning) were no longer remained significant, when mediator variable-inter-organizational knowledge sharing process was controlled (see Table 5, non-significant $\beta$ values ranges from 0.006 to 0.057 ). However, paths between inter-organizational knowledge sharing process (IKSP) and innovative behavioural outcome (IBO) remained significant after controlling for 
inter-organizational knowledge sharing enablers: shared vision $\rightarrow$ IKSP $\rightarrow$ IBO $(\beta=0.499, p<0.001$, $\left.\mathrm{R}^{2}=\mathbf{2 1 . 9} \%\right)$, followed by communication $\rightarrow$ IKSP $\rightarrow$ IBO $\quad\left(\beta=0.477, \quad \mathrm{p}<0.001, \quad \mathrm{R}^{2}=21.7 \%\right)$, commitment $\rightarrow \mathrm{IKSP} \rightarrow \mathrm{IBO} \quad\left(\beta=0.466, \quad \mathrm{p}<0.001, \quad \mathrm{R}^{2}=21.7 \%\right), \quad$ trust $\rightarrow \mathrm{IKSP} \rightarrow \mathrm{IBO} \quad(\beta=0.438, \quad \mathrm{p}<0.001$, $\left.\mathrm{R}^{2}=21.6 \%\right)$ absorptive capacity $\rightarrow$ IKSP $\rightarrow$ IBO $\quad\left(\beta=0.436, \quad \mathrm{p}<0.001, \quad \mathrm{R}^{2}=21.7 \%\right), \quad$ and learning intent $\rightarrow$ IKSP $\rightarrow$ IBO $\left(\beta=0.401, p<0.001, R^{2}=\mathbf{2 2 . 1} \%\right)$. These findings support the full mediation of interorganizational knowledge sharing process between inter-organizational knowledge sharing enablers (except learning intent) and innovative behavioural outcome. However, as shown in table 5 , in the $4^{\text {th }}$ step of multiple regression model, inter-organizational knowledge sharing enabler-learning intent remained significant $(\beta=0.147, p<0.05)$ means that both independent-learning intent and mediatorinter-organizational knowledge sharing process-variables significantly predict dependent variableinnovative behavioural outcome. Thus, the finding supported partial mediation of interorganizational knowledge sharing process between inter-organizational knowledge sharing enablerlearning intent and innovative behavioural outcome. Therefore, these results confirmed hypotheses $4 \mathrm{a}-\mathrm{f}$.

Table 5. Testing of Hypotheses

\begin{tabular}{|c|c|c|c|c|c|}
\hline Step & Regressions & Relationships & $\begin{array}{l}\text { Path } \\
\text { Coefficient }\end{array}$ & $\begin{array}{l}\text { R-square } \\
\text { (percent) }\end{array}$ & $\begin{array}{l}\text { Hypothesis } \\
\text { Testing }\end{array}$ \\
\hline \multirow[t]{6}{*}{ Step 1} & Regression-за & $\mathrm{IKSC} \rightarrow \mathrm{IBO}$ & $0.273^{* *}$ & $7 \cdot 4$ & Hза Accepted \\
\hline & Regression-3b & $\mathrm{IKST} \rightarrow \mathrm{IBO}$ & $0.357^{* *}$ & 10.6 & H3b Accepted \\
\hline & Regression-3c & $\mathrm{IKSSV} \rightarrow \mathrm{IBO}$ & $0.262^{* *}$ & 8.5 & $\mathrm{H}_{3 c}$ Accepted \\
\hline & Regression-3d & $\mathrm{IKSCT} \rightarrow \mathrm{IBO}$ & $0.242^{* *}$ & 8.3 & $\mathrm{H}_{3} \mathrm{~d}$ Accepted \\
\hline & Regression-ze & $\mathrm{IKSL} \rightarrow \mathrm{IBO}$ & $0.160^{* *}$ & $9 \cdot 4$ & Hze Accepted \\
\hline & Regression-3f & $\mathrm{IKSAC} \rightarrow \mathrm{IBO}$ & $0.339^{* *}$ & 11.5 & $\mathrm{H}_{3} \mathrm{f}$ Accepted \\
\hline \multirow[t]{6}{*}{ Step 2} & Regression-2a & IKSC $\rightarrow$ IKSP & $0.557^{* *}$ & 30.7 & Hza Accepted \\
\hline & Regression-2b & IKST $\rightarrow$ IKSP & $0.511^{* *}$ & 25.7 & Hzb Accepted \\
\hline & Regression-2c & $\mathrm{IKSSV} \rightarrow \mathrm{IKSP}$ & $0.622^{* *}$ & 38.5 & Hzc Accepted \\
\hline & Regression-2d & $\mathrm{IKSCT} \rightarrow \mathrm{IKSP}$ & $0.585^{* *}$ & 34.0 & Hzd Accepted \\
\hline & Regression-2e & $\mathrm{IKSL} \rightarrow \mathrm{IKSP}$ & $0.373^{* *}$ & 13.5 & Hze Accepted \\
\hline & Regression-2f & IKSAC $\rightarrow$ IKSP & $0.628^{* *}$ & 39.2 & Hzf Accepted \\
\hline Step 3 & Regression-1 & $\mathrm{IKSP} \rightarrow \mathrm{IBO}$ & $0.459^{* *}$ & 20.7 & Hi Accepted \\
\hline \multirow[t]{12}{*}{ Step 4} & Multiple & $\mathrm{IKSC} \rightarrow \mathrm{IBO}$ & $0.006 \mathrm{~ns}$ & \multirow[t]{2}{*}{21.7} & H4a Accepted full \\
\hline & Regression-4a & $\mathrm{IKSC} \rightarrow \mathrm{IKSP} \rightarrow \mathrm{IBO}$ & $0.477^{* *}$ & & mediation \\
\hline & Multiple & $\mathrm{IKST} \rightarrow \mathrm{IBO}$ & o.o6ons & \multirow[t]{2}{*}{21.6} & $\mathrm{H}_{4} \mathrm{~b}$ Accepted full \\
\hline & Regression- $4 \mathrm{~b}$ & $\mathrm{IKST} \rightarrow \mathrm{IKSP} \rightarrow \mathrm{IBO}$ & $0,438^{* *}$ & & mediation \\
\hline & Multiple & $\mathrm{IKSSV} \rightarrow \mathrm{IBO}$ & o.04ons & \multirow[t]{2}{*}{21.9} & $\mathrm{H}_{4 c}$ Accepted full \\
\hline & Regression-4C & $\mathrm{IKSSV} \rightarrow \mathrm{IKSP} \rightarrow \mathrm{IBO}$ & $0.499^{* *}$ & & mediation \\
\hline & Multiple & $\mathrm{IKSCT} \rightarrow \mathrm{IBO}$ & o.o11ns & \multirow[t]{2}{*}{21.7} & $\mathrm{H}_{4} \mathrm{~d}$ Accepted full \\
\hline & Regression-4d & $\mathrm{IKSCT} \rightarrow \mathrm{IKSP} \rightarrow \mathrm{IBO}$ & $0.466^{* *}$ & & mediation \\
\hline & Multiple & $\mathrm{IKSL} \rightarrow \mathrm{IBO}$ & $0.147^{*}$ & \multirow[t]{2}{*}{22.1} & H4e Accepted \\
\hline & Regression-4e & $\mathrm{IKSL} \rightarrow \mathrm{IKSP} \rightarrow \mathrm{IBO}$ & $0.401^{* *}$ & & partial mediation \\
\hline & Multiple & IKSAC $\rightarrow$ IBO & $0.057 \mathrm{~ns}$ & \multirow[t]{2}{*}{21.7} & $\mathrm{H}_{4} \mathrm{f}$ Accepted full \\
\hline & Regression-4f & $\mathrm{IKSAC} \rightarrow \mathrm{IKSP} \rightarrow \mathrm{IBO}$ & $0.436^{* *}$ & & mediation \\
\hline
\end{tabular}

Note: IKSP=Interorganizational Knowledge Sharing Process, IBO=Innovative Behavioural Outcome, IKSC= Interorganizational Knowledge Sharing Enabler: Communication, IKST= Interorganizational Knowledge Sharing Enabler: Trust, IKSSV= Interorganizational Knowledge Sharing Enabler: Shared Vision, IKSCT= Interorganizational Knowledge Sharing Enabler: Trust, IKSL= Interorganizational Knowledge Sharing Enabler: Learning Intent, IKSAC= Interorganizational Knowledge Sharing Enabler: Absorptive Capacity, ns=Non Significant, ${ }^{*}=\mathrm{p}<0.05,{ }^{* *}=\mathrm{p}<0.001$ 


\section{Discussion and Conclusions}

Altogether, the findings of the current study provided significant support for the logic that relational and social capital facilitates alliance-based behavioural innovation, and this conclusion was more robust indirectly than directly. The six facets of relational and social capital inter-organizational knowledge sharing enablers offered and examined-shared vision, communication, commitment, trust, absorptive capacity, and learning intent-have significant impacts, directly and indirectly through inter-organizational knowledge sharing process, on the innovative behavioural outcome of hospitality alliance firms. These results implied that the degree of knowledge shared among hospitality alliance partners could act as a mediator in the relation between different constructs of relational or social capital facets and behavioural innovative outcome. Specifically, hospitality alliance partners in high relational or social atmosphere of goodwill trust, shared understanding, disposition to share information, commitment to investments in relation-specific or complementary resources, having learning intention, and prior related knowledge or absorptive capacity can generate innovative rents by building up their purposefully superior regular form of inter-organizational knowledge-sharing processes. Thus, social capital facets along with the capability of a firm to identify the worth of novel, outside knowledge, integrate it and put on to commercial ends assists the creation of new knowledge in terms of its accessibility, combination, and exchanging to generate innovations.

Besides, these results confirm the mediating role of knowledge sharing behaviour between social capital and innovation of cultural tourism clusters organizations (CTCs) proved in the study of Martinez-Pérez et al. (2016) which considered both the exploring and exploiting knowledge sharing behaviour as an explanatory mechanism that link the social capital with the advancement of innovation in tourism and hospitality firms. Thus, hospitality alliances firms that are competent to formulate an ambidextrous knowledge strategy by making-capital of their social networks in a complementary means are also more predictable to be innovators. Moreover, the current study also found the partial mediation of knowledge sharing behaviour between knowledge sharing enablerlearning intent-and innovative behavioural outcome of hospitality alliance firms. This implied that both learning intent and knowledge sharing behaviour are equally important in generating innovative behaviour of hospitality firms. These findings are in accordance with previous results of Kim et al. (2013) which indicated that hotel employees' learning goal orientation has a positive impact on their knowledge-sharing behaviours, which in turn impact positively on their service innovative behaviour.

The findings of current study specifically endorse the basic propositions of relational view and social capital that (a) networks of relationships are an invaluable asset (i.e., capital-strong ties, trust, shared goal) to acquire knowledge and innovation (Inkpen \& Tsang, 2005, p.150-151), and (b) relational rentssupernormal profit-are feasible when alliance firms combine, exchange, or commit relation-specific complementary resources and capabilities, knowledge sharing practices-absorptive capacity, transparency and lack of free riding, and trust-based governance methods that reduce transaction costs or enable leveraging of rents by the synergistic blend of resources, and capabilities or knowledge (Dyer \& Singh, 1998, p. 662).

In conclusion, these results implied that intensity around knowledge-based relational and collaborative models of innovation (e.g., service-dominant paradigm - Vargo \& Lusch, 2004; open innovation - Chesbrough, 2003) in terms of knowledge sharing that manifests while collaborating with alliances partners to generate innovation is penetrating over hospitality and tourism sectors, where stiff competition induces collaborative innovation and marketing an important prerequisite for survival of hospitality organizations and destinations.

Theoretical Contribution 
The current study augments the current cultural and creative industry research on knowledge sharing (Kim et al., 2013; Martínez-Pérez et al., 2016; Zach \& Hill, 2017; Kim \& Shim, 2017; García-Villaverde et al., 2017; Liu, 2018) by integrating relational view (Dyer \& Singh, 1998) and social capital theory (Nahapiet \& Ghoshal, 1998) with knowledge-based view (Kogut \& Zander, 1992) of collaborative innovation (Schumpeter, 1934) as a comprehensive model. The conceptual framework offered in the current research investigates the interplay between different facets of relational and social capital, with inter-organizational knowledge sharing process and innovative behaviour in a fast-changing global environment of the hospitality and tourism sector. The findings demonstrate that distinct facets of relational and social capital are vital accelerators and significantly contribute towards interfirm knowledge sharing; therefore, impacting innovative behaviour of hospitality alliance firms positively. Further, inter-organizational knowledge sharing behaviour can perform an intermediary mechanism between social capital and relational constructs and innovative behaviour of hospitality firms of alliance networks (Liu, 2018).

Besides, by establishing inter-firm knowledge sharing as a basis of collaborative innovation in strategic hospitality alliances, the current study contributes towards the extension of resource-based perspective as put forth in the learning and knowledge-based views of the organization (Grant, 1996; Kogut \& Zander, 1992). More specifically, the current research, theoretically and empirically establishes that an alliances relational and social capital' constructs trigger alliance partner' innovative behaviour through inter-firm knowledge sharing in the context of strategic hospitality alliances. Therefore, hospitality alliance firms that benefit from relational and social capital knowledge-based resources of alliance firms can develop effective knowledge management and engender further innovation. To our knowledge, there are limited research concentrating on inter-organizational knowledge sharing behaviour and its relationship with the relational and social aspects as precursors to collaborative innovation within the context of hospitality alliances of national and international branded 4- and 5-star hotels. Thus, the current study adds to the theoretical connection of the relational view, social Capital theory through the knowledge-based view of collaborative innovation, especially within the context of hospitality alliances.

Besides, one more contribution of current research is the analysis of determinants of innovation in under-researched sector i.e., cultural destinations. Besides, the current research produces the factual recognition of historic cities of Turkey as cultural destinations, so emphasizing the appropriateness of world heritage cities as a symbol of cultural identity, heritage and sense of belonging to investigate interfirm relationships across hospitality alliance firms having diverse relationships, origin, and strong global competition (Liu, 2018).

Finally, the findings portray the significance convergence of strategic management and entrepreneurship by suggesting that hospitality firms through strategic alliances may generate value by offering collaborative innovative experience to the customers. As such, entrepreneurship literature underscores the value of capitalizing external knowledge-based resources and creating new combinations through relational and social capital by 4 and 5 star hotels operating in cultural hospitality and tourism alliances.

\section{Practical Contribution}

Keeping in view the importance, challenges, and growth offered by the increasingly sharing and networked-based economy, the findings of the current study imply that the Traveling and Tourism (T\&T) industry of Turkey in its policy agenda should recognize that relational and social capitalcommunication, trust, shared vision, commitment, absorptive capacity, and learning intent-based 
knowledge sharing hospitality strategic alliances can be a vital foundation of innovativeness. Especially, the senior executives of national and international 4 and 5-star certified Turkish hotels should consider these relational assets as significant within the context of hospitality and tourism domains where diverse players participate in marketing, innovation, and management of tourism destinations and offerings. However, to materialize the agenda of innovation, partnerships, and sharing, the hospitality industry especially of Turkey with their new business models will have to orchestrate the collaborative relationships, networks carefully, and knowledge sharing processes, to further offer innovative and varied local hospitality experiences of Turkish based world heritage destinations that are particularly redolent of their local culture. In other words, the leveraging of collaborative innovation through the synergistic combination of knowledge-based resources is feasible only when partners in Turkish based hospitality strategic alliances are ready to combine, exchange, or commit relation-specific complementary capabilities and resources, knowledge sharing practicesabsorptive capacity, transparency, and trust-based governance mechanisms. Hence, for hospitality industry, collaborative innovation is an effective approach only provided the conditions in recognizing the requisite knowledge-based commercial, cultural, operational, and strategic synergies in creating alliances with diverse external allies.

\section{Limitations and further research}

Although the current study has advanced to the understanding of how knowledge-based relational and social capital resources act to enhance the innovation performance of hospitality alliance firms directly and indirectly through inter-organizational knowledge sharing behaviour, however, some limitations also exist. One of these is the generalization of its findings. As previously discussed, the sample of this study only consists of 4 and 5 star national and international hotels operating in cultural cities of Istanbul and Antalya, while hotels with other star ratings with different locations as well contexts in terms of users/customers, SMEs, policies, practices, social media, emerging technologies, and e-tourism are all critical to the phenomena of collaborative innovation. Therefore, keeping in view the heterogeneity in hospitality firms having different traits, the results may be generalized accordingly. However, the findings can be conjectured to the breadth of the current research population. Subsequently, the current research framework can be applied to another type of collaborative relationships and referred contexts to make a comparative research between them (Nieves, Quintana, \& Osorio, 2014).

Finally, although structural equation modeling (SEM) offers justifications identical to multiple regression, still, variances exist. Since SEM has a distinctive capacity to investigate several dependence paths simultaneously. Moreover, the application of SEM to investigate strategic management issues has amplified dramatically in recent years, so the current research model can be examined with SEM approach to produce more robust findings (Shook, Ketchen, Hult, \& Kacmar, 2004).

\section{References}

Acharya, A. S., Prakash, A., Saxena, P., \& Nigam, A. (2013). Sampling: Why and how of it. Indian Journal of Medical Specialties, 4(2), 330-333.

Asheim, B. T., Boschma, R., \& Cooke, P. (2011). Constructing regional advantage: Platform Policies based on related variety and differentiated knowledge bases. Regional Studies, 45(7), 893-904.

Barile, S., Ciasullo, M. V., Troisi, O., \& Sarno, D. (2017). The role of technology and institutions in tourism service ecosystems: Findings from a case study. The TQM Journal, 29(6), 811-833.

Baron, R. M. and Kenny, D. A. (1986). The Moderator-Mediator Variable Distinction in Social Psychological Research: Conceptual, Strategic, and Statistical Considerations. Journal of Personality and Social Psychology, 51(6), 1173-1182. 
Beaumont, N., \& Dredge, D. (2010). Local tourism governance: A comparison of three network approaches. Journal of Sustainable Tourism, 18, 7-28.

Beritelli, P. (2011). Do actors really agree on strategic issues? Applying consensus analysis of stakeholder perceptions in tourist destination communities. Tourism Analysis, 16(3), 219-241.

Brislin, R.W. (1980). Translation and content analysis of oral and written materials. In Triandis, H.C.and Berry, J.W. (Eds). Handbook of Cross-Cultural Psychology: Methodology. Allyn \&Bacon, Boston, MA, 389-444.

Camisón, C., Boronat-Navarro, M., \& Forés, B. (2018). The interplay between firms' internal and external capabilities in exploration and exploitation. Management Decision. 56(7), 1559-1580.

Capaldo, A., \& Petruzzelli, A. M. (2014). Partner geographic and organizational proximity and the innovative performance of knowledge-creating alliances. European Management Review, 11(1), 6384.

Carmeli, A., Gelbard, R., \& Reiter-Palmon, R. (2013). Leadership, creative problem-solving capacity, and creative performance: The importance of knowledge sharing. Human Resource Management, 52(1), 95-121.

Chathoth, P. K., \& Olsen, M. D. (2003). Strategic alliances: a hospitality industry perspective. International Journal of Hospitality Management, 22(4), 419-434.

Chen, C-J. (2004). The Effects of Knowledge Attribute, Alliance Characteristics, and Absorptive Capacity on Knowledge Transfer Performance. RED Management, 34(3), 311-321.

Chen, M. H., Wang, H. Y., \& Wang, M. C. (2018). Knowledge sharing, social capital, and financial performance: the perspectives of innovation strategy in technological clusters. Knowledge Management Research E Practice, 16(1), 89-104.

Chen, Y. H., Lin, T. P., \& Yen, D. C. (2014). How to facilitate inter-organizational knowledge sharing: The impact of trust. Information \& Management, 51(5), 568-578.

Chesbrough, H. (2003). The logic of open innovation: managing intellectual property. California Management Review, 45(3), 33-58.

Chesbrough, H. (2017). The Future of Open Innovation: IRI Medal Address The future of open innovation will be more extensive, more collaborative, and more engaged with a wider variety of participants. Research-Technology Management, 6o(6), 29-35.

Chesbrough, H., \& Bogers, M. (2014). Explicating open innovation: Clarifying an emerging paradigm for understanding innovation. In H. Chesbrough, W. Vanhaverbeke, \& J. West (Eds.). New frontiers in open innovation (pp. 3-28), Oxford: Oxford University Press.

Cochran, W. G. (1963). Sampling techniques. John Wiley and Sons, New York. Second Edition.

Denicolai, S., Cioccarelli, G., \& Zucchella, A. (2010). Resource-based local development and networked core-competencies for tourism excellence. Tourism Management, 31(2), 260-266.

Drucker, P. F. (1993). The rise of the knowledge society. Wilson Quarterly, 17(2), 52-71.

Dwyer, F. R., Schurr, P. H., \& Oh, S. (1987). Developing buyer-seller relationships. The Journal of marketing, 51(2), 11-27.

Dyer, J. H., \& Singh, H. (1998). The relational view: Cooperative strategy and sources of interorganizational competitive advantage. Academy of Management Review, 23(4), 66o-679.

Easterby-Smith, M., Lyles, M. A., \& Tsang, E. W. (2008). Inter-organizational knowledge transfer: Current themes and prospects. Journal of management studies, 45(4), 677-69o.

Elche, D., Martínez-Pérez, Á. \& García-Villaverde, P. M. (2017). Inter-Organizational Relationships, Knowledge Strategy and Innovation in Clusters of Cultural Tourism. Investigaciones Regionales, (39), 17-37.

Ernst Young (2017), Tourism Industry Oversea. Retrieved from.www.ey.com/Publication/.../EY.../eygreater-los-angeles-hospitality-trends.PDF 
García-Villaverde, P. M., Elche, D., Martínez-Pérez, Á. \& Ruiz-Hortega, M. J. (2017). Determinants of radical innovation in clustered firms of the hospitality and tourism industry. International Journal of Hospitality Management, 61, 45-58.

Gomezelj, D. O. (2016). A systematic review of research on innovation in hospitality and tourism. International Journal of Contemporary Hospitality Management, 28(3), 516-558.

Gliem, J. A., \& Gliem, R. R. (2003). Calculating, interpreting, and reporting Cronbach's alpha reliability coefficient for Likert-type scales. Midwest Research-to-Practice Conference in Adult, Continuing, and Community Education.

Granovetter, M. (2005). The impact of social structure on economic outcomes. Journal of economic perspectives, 19(1), 33-50.

Grant, R. M. (1996). Toward a knowledge-based theory of the firm. Strategic management journal, $17(\mathrm{~S} 2)$, 109-122.

Grant, R. M., \& Baden-Fuller, C. (200o). Knowledge and economic organization: an application to the analysis of interfirm collaboration. In Knowledge Creation (pp. 113-150). Palgrave Macmillan, London.

Greer, C. R., Lusch, R. F., \& Vargo, S. L. (2016). A service perspective. Organizational Dynamics, 1(45), 28-38.

Gulati, R. (1999). Network location and learning: The influence of network resources and firm capabilities on alliance formation. Strategic management journal, 20(5), 397-420.

Gundlach, G. T., Achrol, R. S., \& Mentzer, J. T. (1995). The structure of commitment in exchange. The Journal of Marketing, 59(1), 78-92.

Hair, J. F., Black, W. C., Babin, B. J., Anderson, R. E., \& Tatham, R. L. (1998). Multivariate data analysis. Vol. 5, No 3. Uppersaddle River, NJ: Prentice Hall

Hall, C.M. (1999). Rethinking collaboration and partnership: A public policy perspective. Journal of Sustainable Tourism, 7(3-4): 274-289

Hamel, G. (1991). Competition for competence and interpartner learning within international strategic alliances. Strategic management journal, $12(\mathrm{S1}), 83-103$.

Hansen, M. T. (1999). The search-transfer problem: The role of weak ties in sharing knowledge across organization subunits. Administrative science quarterly, 44(1), 82-111.

Hassan, M., \& Ayub, A. (2019). Women's experience of perceived uncertainty: insights from emotional intelligence. Gender in Management: An International Journal, doi.org/10.1108/GM-02-2019-0016.

Hjalager, A.-M. (2010a). A review of innovation research in tourism. Tourism Management, 31(1), 1-12.

Hjalager, A.-M. (2010b). Regional innovation systems: The case of angling tourism. Tourism Geographies: An International Journal of Tourism Space, Place and Environment, 12(2), 192-216

Hu, M. L. M., Horng, J. S., \& Sun, Y. H. C. (2009). Hospitality teams: Knowledge sharing and service innovation performance. Tourism management, 30(1), 41-50.

Hurt, H. T., Katherine J and Chester, D. C. (1977). Scales for the Measurement of Innovativeness. Human Communication Research, 1(1), 58-65.

Idrees, I. A., Vasconcelos, A. C., \& Ellis, D. (2018). Clique and elite: inter-organizational knowledge sharing across five-star hotels in the Saudi Arabian religious tourism and hospitality industry. Journal of Knowledge Management, 22(6), 1358-1378.

Inkpen, A. C. (1992). Learning and collaboration: An examination of North American-Japanese joint ventures. Unpublished doctoral dissertation, The University of Western Ontario

Inkpen, A. C. (1997). An examination of knowledge management in international joint ventures. In P.W. Beamish and P. J. Killing (Eds.), Cooperative Strategies: North-American perspective (pp. 337-369). San Francisco: The New Lexington.

Inkpen, A. C. (1998). Learning and knowledge acquisition through international strategic alliances. The Academy of Management Executive, 12(4), 69-80. 
Inkpen, A. C. (200o). Learning through joint ventures: a framework of knowledge acquisition. Journal of management studies, 37(7), 1019-1044.

Inkpen, A. C., \& Crossan, M. M. (1995). Believing is seeing: Joint ventures and organization learning. Journal of management Studies, 32(5), 595-618.

Inkpen, A. C., \& Tsang, E. W. (2005). Social capital, networks, and knowledge transfer. Academy of management review, 30(1), 146-165.

Investment support and promotion agency of Turkey (2018). Invest in Turkey. Retrieved from http://www.invest.gov.tr/en-US/sectors/Pages/WellnessAndTourism.aspx

Jamal TB \& Getz D. (1995). Collaboration theory and community tourism planning. Annals of Tourism Research, 22(1), 186-204

Jetter, L. G., \& Chen, R. J. (2012). An exploratory investigation of knowledge sharing and cooperative marketing in tourism alliances. International Journal of Hospitality $\mathcal{E}$ Tourism Administration, 13(2), 131-144.

Kale, P., Singh, H. \& Perlmutter, H. (20oo). Learning and Protection of Proprietary Assets in Strategic Alliances: Building Relational Capital. Strategic Management Journal, 21, 217-237

Kim, N., \& Shim, C. (2017). Taking it personally: How to increase interorganizational knowledge sharing in a tourist district. Tourism and Hospitality Research, 19(1), 85-97.

Kim, T., Lee, G., Paek, S., \& Lee, S. (2013). Social capital, knowledge sharing and organizational performance: what structural relationship do they have in hotels? International Journal of Contemporary Hospitality Management, 25(5), 683-704.

Kogut, B. and Zander, U. (1992). Knowledge of the firm, combinative capabilities, and the replication of technology. Organization Science, 3, 383-397.

Koo, C., Ricci, F., Cobanoglu, C., \& Okumus, F. (2017). Special issue on smart, connected hospitality and tourism. Information Systems Frontiers, 19(4), 699-703.

Köseoglu, M. A., Yazici, S., \& Okumus, F. (2017). Barriers to the implementation of strategic decisions: evidence from hotels in a developing country. Journal of Hospitality Marketing $\mathcal{E}$ Management, 130.

Lane, P. J., \& Lubatkin, M. (1998). Relative absorptive capacity and interorganizational learning. Strategic management journal, 461-477.

Levitt, B., \& March, J. (1988). Organizational learning. Annual Reviews, 14, 319-340

Likert, R. (1932). A Technique for the Measurement of Attitudes. New York: Archives of Psychology.

Li, C. H., \& Chang, C. M. (2016). The influence of trust and perceived playfulness on the relationship commitment of hospitality online social network-moderating effects of gender. International Journal of Contemporary Hospitality Management, 28(5), 924-944.

Liu, C. H. S. (2018). Examining social capital, organizational learning and knowledge transfer in cultural and creative industries of practice. Tourism Management, 64, 258-270.

Maggioni, I., Marcoz, E. M. And Mauri, C. (2014). Segmenting networking orientation in the hospitality industry: an empirical research on service bundling. International Journal of Hospitality Management, 42, 192-201.

Martínez-Pérez, Á. García-Villaverde, P. M., Elche, D. (2016). The mediating effect of ambidextrous knowledge strategy between social capital and innovation of cultural tourism clusters firms. International Journal of Contemporary Hospitality Management, 28(7), 1484-1507

Merlo, O., Bell, S. J., Mengüç, B., \& Whitwell, G. J. (2006). Social capital, customer service orientation and creativity in retail stores. Journal of Business Research, 59(12), 1214-1221.

Ministry of Culture and Tourism (2007) Tourism Strategy of Turkey-2023. Retrieved from www.kultur.gov.tr/EN,13878o/tourism-strategy-of-turkey.html

Molina-Morales, F. X., \& Martínez-Fernández, M. T. (2010). Social networks: effects of social capital on firm innovation. Journal of Small Business Management, 48(2), 258-279. 
Morgan, R. M., \& Hunt, S. D. (1994). The commitment-trust theory of relationship marketing. The journal of marketing, 20-38.

Nahapiet J, Ghoshal S. 1998. Social capital, intellectual capital and the organizational advantage. Academy of Management Review, 23, 242-266

Nieves, J., \& Osorio, J. (2013). The role of social networks in knowledge creation. Knowledge Management Research \& Practice, $11(1)$, 62-77.

Nieves, J., Quintana, A., \& Osorio, J. (2014). Knowledge-based resources and innovation in the hotel industry. International Journal of Hospitality Management, 38, 65-73.

Nonaka, I. (1994). A dynamic theory of organizational knowledge creation. Organization Science, 5, 1437.

Nonaka, I., \& Takeuchi, H. (1995). The knowledge-creating company: How Japanese companies create the dynamics of innovation. New York: Oxford university press.

Norman, P. M. (2004). Knowledge acquisition, knowledge loss, and satisfaction in high technology alliances. Journal of Business Research, 57(6), 610-619.

OECD/Eurostat. (2005). Oslo Manual: Guidelines for collecting and interpreting innovation data (3rd ed.). Paris: OECD Publishing.

Okumus, F. (2013). Facilitating knowledge management through information technology in hospitality organizations. Journal of Hospitality and Tourism Technology, 4(1), 64-8o.

Okumus, F., Altinay, L., \& Chathoth, P. (2010). Strategic Management in the International Hospitality and Tourism Industry. London: Routledge.

Ottenbacher, M., \& Gnoth, J. (2005). How to develop successful hospitality innovation. Cornell Hotel and Restaurant Administration Quarterly, 46(2), 205-222.

Pace, L. A. (2016). How do tourism firms innovate for sustainable energy consumption? A capabilities perspective on the adoption of energy efficiency in tourism accommodation establishments. Journal of Cleaner Production, 111, 409-420.

Peltokorpi, V. (2017). Absorptive capacity in foreign subsidiaries: The effects of language-sensitive recruitment, language training, and interunit knowledge transfer. International Business Review, 26(1), 119-129.

Pfeffer, J., \& Salancik, G. R. (1978). The external control of organizations: A resource dependence approach. NY: Harper and Row Publishers.

Prahalad, C. K., \& Ramaswamy, V. (2004). Co-creation experiences: The next practice in value creation. Journal of interactive marketing, 18(3), 5-14.

Provan K. G. (1983). The federation as an interorganizational linkage network. Academy of Management Review, 8: 79-89.

Reagans, R., \& McEvily, B. (2003). Network structure and knowledge transfer: The effects of cohesion and range. Administrative science quarterly, 48(2), 240-267.

Rodríguez-Díaz, M., \& Espino-Rodríguez, T. F. (2006). Developing relational capabilities in hotels. International Journal of Contemporary Hospitality Management, 18(1), 25-40.

Saraniemim, S., \& Kylanen, M. (2011). Problematizing the concept of tourism destination: An analysis of different theoretical approaches. Journal of Travel Research, 50(2), 133-143

Schumpeter, J.A., (1934). The Theory of Economic Development. Cambridge: Harvard University Press.

Serrat, O. (2017). Learning in strategic alliances. In Knowledge Solutions (pp. 639-647). Singapore: Springer.

Shaw G \& Williams A. (2009). Knowledge transfer and management in tourism organisations: An emerging research agenda. Tourism Management, 30(3), 325-335.

Shook, C. L., Ketchen, D. J., Hult, G. T. M., \& Kacmar, K. M. (2004). An assessment of the use of structural equation modeling in strategic management research. Strategic management journal, 25(4), 397-404. 
Tang, T. W. (2016). Making innovation happen through building social capital and scanning environment. International Journal of Hospitality Management, 56, 56-65.

Tang, T. W., Wang, M. C. H., \& Tang, Y. Y. (2015). Developing service innovation capability in the hotel industry. Service Business, 9(1), 97-113.

Tzokas, N., Kim, Y. A., Akbar, H., \& Al-Dajani, H. (2015). Absorptive capacity and performance: The role of customer relationship and technological capabilities in high-tech SMEs. Industrial Marketing Management, 47, 134-142.

UNWTO (2018). Tourism and the Sustainable Development Goals-Journey to 2030 HIGHLIGHTS. Retrieved from https://www.e-unwto.org/doi/pdf/10.18111/9789284419401 dated 4.3.2018

Van Niekerk, M., De Martino, M., \& Scott, N. (2017). Introduction: Tourism Knowledge Transfer. In Knowledge Transfer to and within Tourism: Academic, Industry and Government Bridges (pp. 3-9). UK: Emerald Group Publishing Limited.

Vargo, S. L., \& Lusch, R. F. (2004). Evolving to a new dominant logic for marketing. Journal of marketing, 68(1), 1-17.

Von Friedrichs Grängsjö, Y., \& Gummesson, E. (2006). Hotel networks and social capital in destination marketing. International Journal of Service Industry Management, 17(1), 58-75.

Wang, Y., \& Xiang, Z. (2007). Toward a theoretical framework of collaborative destination marketing. Journal of Travel Research, 46(1), 75-85.

Williamson, O. E. (1975). Markets and hierarchies: Analysis and Antitrust Implications. New York: Free Press.

Williams, B., Onsman, A., \& Brown, T. (2010). Exploratory factor analysis: A five-step guide for novices. Journal of Emergency Primary Health Care (JEPHC), 8(3). 1-13.

World Economic Forum. (2017). The travel and tourism competitiveness report. Retrieved from http://www3.weforum.org/docs/WEF_TTCR_2017_web_0401.pdf

Yang, J.-T. And Wan, C.S. (2004). Advancing organizational effectiveness and knowledge management implementation. Tourism Management, 25(5), 593-601.

Yli-Renko, H., Autio, E., \& Sapienza, H. J. (2001). Social capital, knowledge acquisition, and knowledge exploitation in young technology-based firms. Strategic management journal, 22(6-7), 587-613.

Zach, F. (2016). Collaboration for innovation in tourism organizations: leadership support, innovation formality, and communication. Journal of Hospitality E Tourism Research, 40(3), 271-290.

Zach, F. J., \& Hill, T. L. (2017). Network, knowledge and relationship impacts on innovation in tourism destinations. Tourism Management, 62, 196-207.

Received: 10/12/2018

Accepted: 06/o7/2019

Coordinating editor: Martina Gonzalez-Gallarza 